Brit. J. vener. Dis. (1966), 42, 263.

\title{
HISTORY OF HERPES GENITALIS*
}

BY

\author{
DAVID C. HUTFIELD \\ Department of Venereal Diseases, The Royal Infirmary, Manchester
}

Mettler (1947) suggested that the first description of herpes febrilis was given by the Roman physician Herodotus, who lived in A.D. 100 in the reign of Trajan. Herodotus described "the herpetic eruptions which appeared about the mouth at the crisis of simple fevers, and the weals of febrile urticaria". Aëtius of Amanda (1949a, b), Royal physician and Lord High Chamberlain at the Court of Byzantium, gives an account of this and a description of the lesions of herpes simplex in the Tetrabiblion.

* Part of a thesis accepted for the M.D. degree of the University of London. Received for publication April 25, 1966.

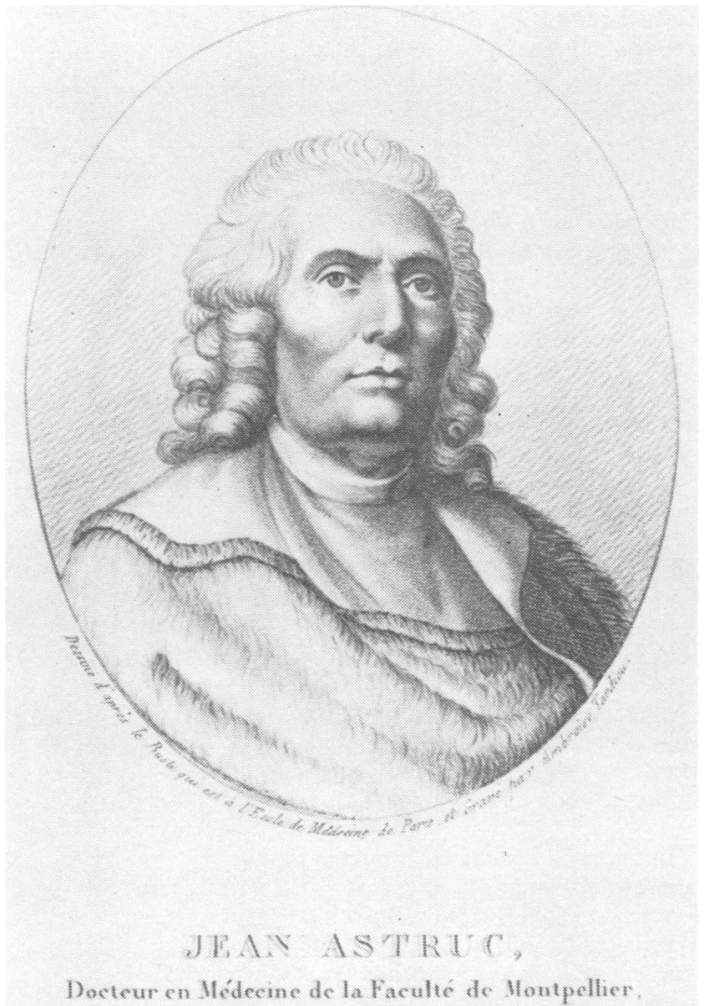

Mrdecin Consultant du Roi et Professeur au Collegede France.

X. A Saune pres Quzssac (Card) le to Mars 3684

Nort is Paris le S Mas a 66
Herpetes were described by Hippocrates, but these are thought to be referable to the febrile eruptions of smallpox.

It was not until 1736 that the classical description of genital herpes was recorded by the French physician, John Astruc (Fig. 1). This was at a time when prostitution in France was under medical surveillance and, in the words of Unna (1883), France was "a country where excellent syphilographers abounded as nowhere else". The original description, which was in Latin, appeared in De morbis venereis (1736) (Fig. 2), and the English

\section{DE MOR B IS V E N E R E I S L I B R I SEX. \\ IN QUIBUS DISSERITUR TUM DE ORIGINE; Propagatione \& Contagione horumce affectuum in genere : tùm de fingulorum Naturâ, Atiologiâ \& $\propto$ Therapeiâ, cum brevi Analyfi \& Epicrifi Operum plerorumque qux de codem argumento fcripta fuat. \\ Auctore JOA N NE A S T R U Regi à Confliis Medicis; Archnatro Augufti II. glorio/a memoria, Poloniarum Regis, S. R. I. Electoris, \& Ducis Saxonis; Medico Ordinario Seren. Principis Ducis Aurelianenfis; $\sigma$ in Regio Francis Collegio Profeffore Medico.
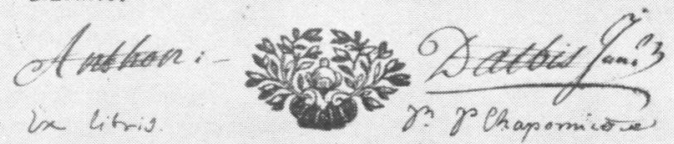 \\ LUTETIE PARISIORUM, Apud GUILLELMUM CAVELIER, vià Jacobxâ, fub figno Lilii Aurci. \\ M. DC C. $\mathrm{X} \times \mathrm{X} \vee \mathrm{t}$. \\ CUM APPROBATIONE ET PRIVILEGIO REGIS.}

Fig. 1.-John Astruc, Physician to the King of France, Professor of Medicine. By courtesy of "The Wellcome Trustees".
FIG. 2.-Title-page of De morbis venereis. By courtesy of "The Wellcome Trustees". 
transcription of this work appeared as a "Treatise of Venereal Diseases in Nine Books" in 1754. Extracts of the original description by John Astruc are as follows (Fig. 3):

“. . In a like manner, of whatever kind of tumour of the glans is, there frequently arise upon the surface of it, which is laid bare in the paraphimosis, or upon the margin of the prepuce, with which it is covered in the phimosis, several hydatids, or watery and crystalline bladders, which are filled with a lymph that is thin, or thick, opaque, or diaphanous, alone, or mixed with the air; differing in number, magnitude, and degree of prominence, sometimes occupying the corona, sometimes the apex, sometimes the back, sometimes the sides of the glans; nay in the phimosis and paraphimosis, they sometimes arise upon the prepuce, or fraenum of the prepuce.

"These disorders are not proper to men alone, but (mutatis mutandis) are common to women from the same cause.

254 DE MORBIS VENEREIS.

$$
\begin{aligned}
& \text { C A P U T V I I I. } \\
& \text { De Afectibus variis, qui ab Ulcufalis venereis genitalium } \\
& \text { dependent, vel iifdem faperveniant. } \\
& \text { 5. I. DE TUMORIBUS PRAPUTII ET BALANI; } \\
& \text { UBI DE PHIMOS1, PARAPHMOSI IT CRYSTALINA. }
\end{aligned}
$$

Defcriptio. $D$ Efcriptio. Si ulcufcula, quz internam prapurii faciem franumve, aut ipfum balani dorfum coronamve obfident, multa, conferta, maligna, dolorifica fint, aut fortiorum efcharoticorum abufu nimis irritentur, contingit inde glifcente labe ut vel praputium, vel balanus, vel uterque fimul brevi inferur, craflefcat, tumeat.

1. Tumo- I. Prxpurium autem balanufque, cùm inflantur, $x^{0}$. Modo calent, doxis prapu- lent, rubent, prementi digito xgrè cedunt, \& ceffante preffione promptè tii \& bala- reftituuntur; atque rumor ille inflammatorius five phiegmonodes.

ni.

$2^{\circ}$. Modò verô caloris, doloris, ruboris expertia videntur quafi pellucere fero turgida, \& prementi digito ita cedunt, ut impreffum veftigium diù rerineant; atque rumor ille forofus feu $\propto$ dewatodes.

$3^{\circ}$. Denique modo caloris, doloris \& ruboris expertia quidem funt, fed fimul ita renitentia ac dura, ut digiti preffionem eludant; atque tumor ille durus feu skirrhodes appellatur.

II. Phimo 11. Porrò prxputium, quâcumque ratione intumefcat, mod̀̀ in extrefeos \& $\mathrm{Pa}$ - mo limbo coarctarum glandem ita ftricè concludit, ut ad pofteriora deraphimo- duci non poffit, \& ille ftatus graco nomine phimofis dicitur, hoc eft liga-
feos. teos. tringitur, ut ad anteriora adduci nullâ arte queat ; \& ftatus ille procedenti contrarius, paraphimofis appellatur, hoc eft circum-ligatura.

III. Et bul. III. Pari ratione qualifcumque fuerit balani tumor, folent non rarb, fr larum cryf- infarclus gravior \& duturnior fit, ex ejufder facie que in paraphimofi callisarum. denudata oft, vel ex margine praputii quo contegirur in phimofi hydatides emergere feu bulle aquofe ơ cryflallina, qux plenx limphâ tenui vel crafsâ, limpidâ vel fubruffâ, opacâ vel diaphanả, folâ vel cum aete permîtâ; numero, magnirudine, prominentiầ varix, modò fummum glandis apicem, modò coronam, modó dorfum, modò latera occupant; quin imò. eftlorefcunt quandoque in phimofi \& paraphimofi ex ipfo praputio proputiive freno.

I Pares fimi- Hac autem fingula non virorum tantùm propria funt, fed mutaris mu-

caque af- tandis mulieribus quoque communia ex ê̂dem causâ.

cblervan-

tur tum in

Nam $1^{\circ}$. Vulv $x$ labia, nymph $x$ five pterygia, clitoris ac clitoridis pro-

forminis. putium, \& carunculx myrtiformes qux vaginx oftium obvallant, fi ulcufculis defxdentur malignioribus, tument \& inflantur pari modo ac prapurium aut glans in viris; tumorque inde obortus fimili prorsis ratione inflammatorius, adematodes vel skirnbodes eft.

$2^{\circ}$. Quod fi carunculx myrtiformes aus vaginx oftium uicufculis gram-

FIg. 3.-The original description of herpes genitalis from De morbis venereis. By courtesy of "The Wellcome Trustees". 
"For 1. The labia pudendi, nymphae, clitoris, and its prepuce, as also the carunculae myrtiformes at the orifice of the vagina, being beset with malignant chancres, become swelled and inflated in the same manner as the prepuce or glans in men; and the tumour arising from thence is for the same reason determined to be inflammatory, odematous or schirrous.

"If the carunculae myrtiformes, or orifice of the vagina, are beset with very malignant chancres, a violent stricture of the vagina will be brought on, which may justly be called a phimosis.

"Nay sometimes from the surface of the swelled parts there push out hydatids, or vesicles full of lymph, which in their figure, quality, and nature resemble the crystallines which arise in men.

"Something of this kind is observed in catamites and pathics, if they contract foul ulcers in the anus by the unnatural use of venery; from these ulcers they are tormented with a grievous inflammation upon the extremity of the rectum and a straitness or phimosis of the podex ... hence the evacuation of the faeces becomes difficult and painful, and the malignancy of the disease daily increasing, if it be neglected, crystalline bladders frequently push forth at the margin of the anus exactly like the bladders which we have justly now described".

From this description it is realized that Astruc did not give a particular name to the condition; this was left to Alibert (1832), senior physician to the Hopital Saint Louis in Paris, who described the condition as l'Olophlyctide progéniale, and stated that "it locates itself not only on the prepuce, but also at the introitus vaginae; if we have fewer opportunities of observing it there, it is on account of the natural modesty of sex, for preputial and pre-vaginal olophlyctide are of an absolutely equal element". Boret (1838) described the condition as herpès phlycténoide and said that it could present in various forms, such as herpes preputialis, herpes vulvaris, herpes labialis, and as a ring form or herpes circinatus.

Greenough (1881) had a paper read at the fourth meeting of the American Dermatological Association, which was held in 1880 , and emphasized that in his experience genital herpes was seen only in males, and that its inordinately high incidence in patients with histories of venereal disease and its further tendency towards recurrence after sexual intercourse, led him to suspect a relationship to venereal infection. Discussion of the paper brought a difference of opinion whether there was necessarily any relationship to venereal infection; it was pointed out that only persons who had had a suspected exposure to venereal disease consulted physicians for this harmless and transitory affliction. Duhring contributed to the discussion on this subject the statement that he had never seen herpes progenitalis in the female. This impressed Unna to the extent that he produced a paper (Unna, 1883) which recorded a high incidence of genital herpes in females. Unna stated that over a 4-year period he had seen 200 cases of herpes progenitalis in "puellae publicae" at the venereal diseases department of the Hamburg General Hospital. In the years 1878 to 1881,846 prostitutes had attended the hospital and those suffering from herpes progenitalis had formed from 4.7 to 9.1 per cent. of this total. He said that, in women of a "particular class", herpes progenitalis was a "very frequent malady", it was a "vocational disease" of women rather than men, although both sexes were susceptible. He thought that it was related to one common denominator and that was "congestion of the genital organs", which occurs in excess venery, genital discharges, menstruation, pregnancy, obesity, hot weather, rape, impeded penile erection, over-long prepuce, and uncleanliness. He also stated that herpetic eruptions frequently coincided with the "menstrual epoch" and proposed the name bouton de régle. He did not give a detailed analysis of his series, but stated that it would seem important "to ascertain with greater statistical exactitude, in the future, the period of incubation of herpes progenitalis".

In an historical review of the literature at that time, Unna (1883) also stated that in France, as a result of a series of monographs, the comparative status of herpes progenitalis in men and women was recognized a hundred years before herpes in general had received serious attention. $\mathrm{He}$ then quoted Legendre (1853) as having published an essay on herpes progenitalis, with three cases, based on his experience as physician to the Lourcine. He also stated that Prof. J. A. Fournier (1878) of the Hôpital Saint Louis had in two lectures stimulated the clinical study of this subject, and had done much in clarifying knowledge about it. He quoted Duparcque (1832) as having parenthetically described herpes of the portio vaginalis in a Traité théorétique et pratique sur les ulcérations organiques simples et cancéreuses de la matrice. Rollet (1869) was quoted as having described a "blennorrhagic ulceration of the collum uteri" which was attributed to a true herpes by Brunneau, the Professor of Medical Jurisprudence. Finally, he stated that Mauriac (1876) had more accurately described herpes as it occurs in man and which he called l'herpès névralgique. This neuralgic herpes of Mauriac was first described by him in 1876 as l'herpès névralgique des organes génitaux. He stated that he first saw a case at the Hôpital du Midi in 1870 , just before the siege of Paris, and described a further case associated with two recurrent attacks of preputial herpes. On the eleventh day of the first attack paroxysmal pains commenced in the lumbar 
region and radiated to the scrotum, perineum, groins, and thighs. These were associated with hyperaesthetic and anaesthetic areas in these parts and with purulent herpetic lesions. One year later an attack of herpes appeared on the left of the umbilicus, which was preceded for several days by pain in the lumbosacral and ischiosacral regions; later herpetic lesions appeared at the anus and were accompanied by pains in the lower extremities. Unna (1883) thought that some of the cases described were true herpes zoster, but that others might be a type halfway between a true zoster and genital herpes, the true zoster usually being differentiated by its unilateral distribution and its limitation to the terminal distribution points of nerves.

Diday and Doyon (1886) were the first to publish a book on this subject, which was entitled Les herpès génitaux (Fig. 4). In this they recorded observations that genital herpes often appeared after a venereal

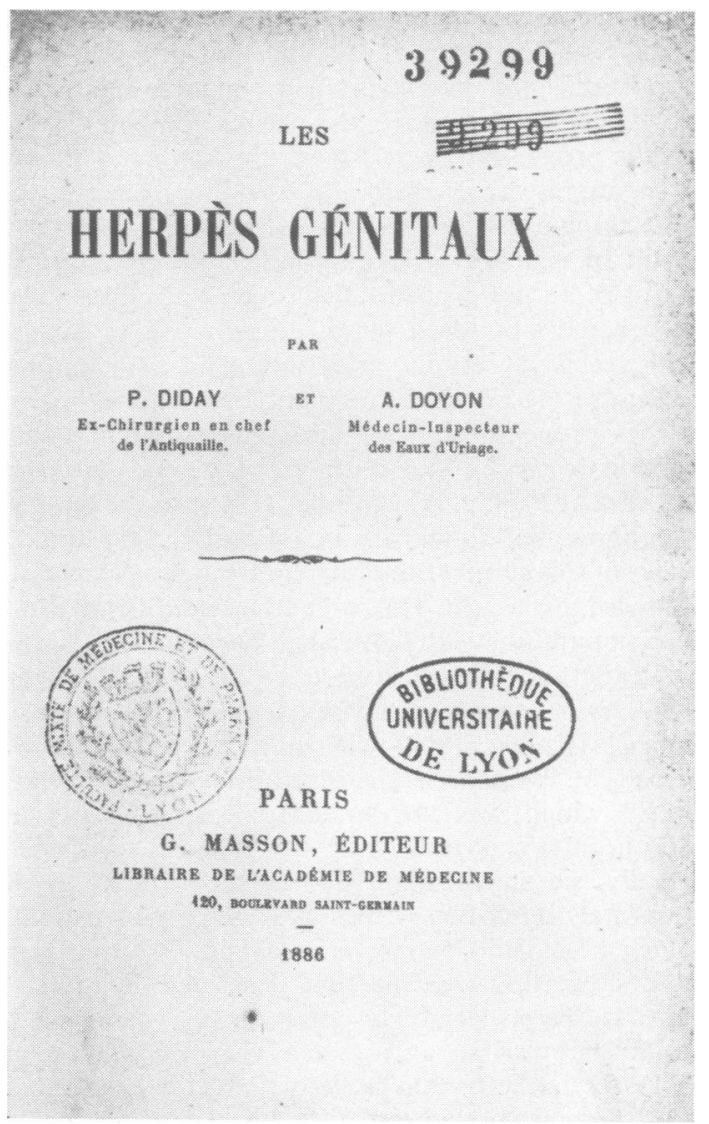

Fig. 4.-Title-page of the one published book on herpes genitalis. By courtesy of the University of Lyons Medical Library. infection, such as syphilitic chancre, chancroid, or gonorrhoea, but that not all patients with venereal diseases developed herpes. They also described 56 cases of genital herpes that recurred with menstruation, and others that were associated with arthritis. They thought the eruptions were related to a nervous "trigger mechanism" acting by way of the sacral plexus and the internal pudendal nerve, except in arthritis in which the mechanism was probably blood-born. Diday and Doyon (1876) were also the first to describe urethritis resulting from endourethral herpes.

Prof. R. Bergh (1890) observed 877 cases of genital herpes during the years 1866 to 1889 , and of these, 644 (73.4 per cent.) were menstrual; the herpes lesions either preceded or followed menstruation, but more often preceded it; in the other 26.6 per cent. of cases the disease was unrelated to menstruation. Levin (1900) also described genital herpes associated with menstruation and quoted figures for the venereal diseases clinic in Berlin from April 1898, until March, 1899, during which time, 1,584 women were seen, of whom 112 (7.07 per cent.) suffered from genital herpes. In 83 (5.2 per cent.) of these the condition was associated with menstruation.

The histology of the herpes genitalis vesicle was first described by Unna (1896), who recorded his observations from three genital specimens, one of which was a mortuary specimen.

As stated above, Prof. J. A. Fournier (1896) made considerable contributions to the subject and attempted to classify genital herpes into two groups, which were designated as constitutional or accidental. Constitutional herpes was the severe and recurrent type, which was often made worse by secondary infection and in some cases had led to suicide. He divided accidental herpes into three sub-groups as follows:

(1) Herpes following injury and surgery, of which attempted rape was listed as a cause of herpes vulvae.

(2) Herpes blennorrhagica - male and female.

(3) Herpes in association with a chancre.

Many and various treatments have been advocated by different writers. Bateman (1813) of Whitby, Yorkshire, made a reference to the treatment of herpes preputialis in his "Practical Synopsis of Cutaneous Diseases". He suggested avoiding irritative, "unctious", or moist applications and advised the interposition of a piece of clean, dry lint twice daily between the prepuce and glans. This he stated would lessen irritation and cause the lesions to heal in 14 days. 
One of the first publications, however, to deal specifically with the treatment of genital herpes was by Sir Jonathan Hutchinson (1890), senior surgeon to The London Hospital. He described the "great benefit" obtained from the long-continued use of arsenic in the form of Fowler's solution in three cases of troublesome recurrent herpes of the prepuce, each of which had followed an attack of syphilis. One patient had suffered from recurrent attacks for 6 years following a chancre; they lasted 7 to 10 days at a time and recurred every 6 weeks, but after he had been given a course of Fowler's solution they cleared up and "he was never to be seen again". In the second patient a course of Fowler's solution reduced the number of attacks from an almost continuous succession following regular intercourse, to four times a year, during which time "he practised abstinence". The third patient had suffered with recurrent preputial herpes for 4 years, but after a year's course of Fowler's solution they became less and finally cleared altogether.

Professor Fournier (1896) discussed the use of topical applications in the treatment of vulval herpes, such as starch poultices, cold creams, bismuth, and talcum powders. He also thought that in recurrent cases the treatment advocated by Prof. M. Verneuil (1889) for catamenial herpes could be tried. This consisted of injections of 5 per cent. ether iodoform subcutaneously in the middle of the herpetic lesions. Professor Fournier thought that the results of treatment could be improved if alcohol and tobacco were forbidden, and if the patient avoided overtiredness and sexual excess. He thought that "moderate coitus with fidelity" was quite permissible since marriage often caused herpes to disappear.

\section{Discussion}

One of the interesting factors about this historical review covering the 18 th and 19 th centuries is that most of the original writings on herpes genitalis were subscribed at professorial level and that French and German writers were pre-eminent in this respect. Sir Jonathan Hutchinson (1890) of The London Hospital was the only British author during this time to publish work dealing particularly with this subject. Some of the older writings also indicate that there may have been a change in the epidemiology of this disease; relatively more female cases were seen by the older writers than by those of to-day and more cases were seen which appeared to be related to menstrual factors; certain complications of the disease that were described have also appeared to have changed in recent years. It was not until the 20th century, however, that the aetiology of this condition emerged.

\section{Summary}

An historical review of the literature on herpes genitalis covering the 18 th and 19th centuries is given. It is noted that most of the descriptive studies during this time were by French and German workers and that Sir Jonathan Hutchinson of The London Hospital was the only British author.

The work on which this thesis was based was done during the tenure of appointments at St. Mary's, The London, and St. Thomas' Hospitals.

I am indebted to $\mathrm{Mr}$ Ambrose King, F.R.C.S., and $\mathrm{Dr}$ E. M. C. Dunlop, M.D., M.R.C.P., Consultant Venereologists, The London Hospital, London, E.1, and to $\mathrm{Dr}$ R. R. Willcox, M.D., Consultant Venereologist, St. Mary's Hospital, London, W.2, for their criticism and advice on the final preparation of the script; to the Wellcome Historical Museum and Library for historical works provided; to Mr Thomas Cassidy of the National Library of Medicine, Washington, D.C., for photocopies of papers otherwise unavailable in Great Britain; to the Royal Society of Medicine for translations; and to the photographic departments of St. Thomas' Hospital and The Wellcome Historical Medical Museum and Library for the photographic prints.

\section{REFERENCES}

Aetius, A. (1549a). “Tetrabibli”, II, serm. II, cap.129, p. 283. (1549b). Ibid., IV, serm. II, cap. 60, p. 893. (By courtesy of "The Wellcome Trustees".)

Alibert, J. L. (1832). "Monographies des dermatoses", p. 89. Daynac, Paris. (By courtesy of "The Wellcome Trustees".)

Astruc, J. (1736). "De morbis venereis", III, VIII, III, 254. Paris.

(1754). "A Treatise of Venereal Diseases", vol. 1, book 3, chap. 8, p. 365 . Innys and Richardson, London. (By courtesy of "The Wellcome Trustees".)

Bateman, T. (1813). "A Practical Synopsis of Cutaneous Diseases", p. 234. Longman, London. (By courtesy of "The Wellcome Trustees".)

Bergh, R. (1890). Mschr. prakt. Derm., 10, 1.

Boret, M. de (1838). J. Méd. Chir. prat. (Paris), 9, 344.

Diday, P., and Doyon, A. (1876). "Thérapeutique des maladies vénériennes et des maladies cutanées", p. 58. Masson, Paris.

(1886). "Les herpès génitaux", p. 122. Paris. (By courtesy of the University of Lyons Library.)

Duparcque, F. (1832). "Traité théorétique et pratique sur les ulcérations organiques simples et cancéreuses de la matrice". Crochard, Paris. (English translation, 1837.) Quoted by Unna (1883).

Fournier, J. A. (1878). Gaz. hôp. (Paris), 51, 890. (By courtesy of "The Wellcome Trustees".)

(1896). Rev. gén. clin. et thérap. (Paris), 10, 177. (By courtesy of the National Library of Medicine, Washington, D.C.)

Greenough, F. B. (1881). Arch. Derm. (N.Y.), 7, 1 (Discussion, p. 67).

Hutchinson, J. (1890). Arch. Surg. (Lond.), 1, 351.

Legendre, F. L. (1853). Arch. gén. Méd., 5 sér., 2, 171.

Levin, E. (1900). Dtsch. med. Wschr., 26, 277, 293.

Mauriac, M. (1876). Gaz. hôp. (Paris), 49, 83. (By courtesy of The "Wellcome Trustees".) 
Mettler, C. C. (1947). "History of Medicine", ed. F. A. Mettler, p. 356. Blakiston, Philadelphia.

Rollet, J. (1869). Ann. Derm. Syph. (Paris), 1, 100.

Unna, P. G. (1883). J. cutan. vener. Dis., 1, 321.

(1896). "The Histopathology of the Diseases of the Skin", p. 145. Clay, Edinburgh. (By courtesy of "The Wellcome Trustees".)

Verneuil, M. (1889). " 1 e Congr. int. Derm. Syph., 1890", p. 158. (By courtesy of the National Library of Medicine, Washington, D.C.)

\section{L'historique de l'herpès génitale}

RÉSUMÉ

Une revue historique de la littérature au sujet de l'herpès génitale au 18 ème et 19ème siècles est donnée. Il est noté que la plupart des études descriptives pendant ces périodes étaient faites par des observateurs français et allemands et que Sir Jonathan Hutchinson du London Hospital fut le seul auteur anglais. 